\title{
Diversity and habitat use by snakes and lizards in coastal environments of southernmost Brazil
}

\author{
Maurício Beux dos Santos ${ }^{1,4}$, Mauro Cesar Lamim Martins de Oliveira ${ }^{2}$ \& Alexandro Marques Tozetti $^{3}$ \\ ${ }^{1}$ Laboratório de Ecologia de Vertebrados Terrestres, Instituto de Ciências Biológicas, Universidade Federal \\ do Rio Grande - FURG, Campus Carreiros, Av. Itália, Km 8, CEP 96201-900, Rio Grande, RS, Brasil \\ ${ }^{2}$ Laboratório de Ictiologia, Instituto de Oceanografia, Universidade Federal do Rio Grande - FURG, \\ Campus Carreiros, CP 474, CEP 96201-900, Rio Grande, RS, Brasil \\ ${ }^{3}$ Universidade do Vale do Rio dos Sinos - UNISINOS, Av. Unisinos, 950, \\ CEP 93022-000, São Leopoldo, RS, Brasil \\ ${ }^{4}$ Corresponding author: Maurício Beux dos Santos, e-mail: mbeuxs@yahoo.com.br
}

SANTOS, M.B., OLIVEIRA, M.C.L.M. \& TOZETTI, A.M. Diversity and habitat use by snakes and lizards in coastal environments of southernmost Brazil. Biota Neotrop. 12(3): http://www.biotaneotropica.org.br/ v12n3/en/abstract?article+bn01812032012

\begin{abstract}
This study examined species composition differences among snake and lizard assemblages from coastal dunes and restinga habitats in southernmost Brazil. Animals were collected between April 2009 and March 2010 using pitfall traps, artificial shelters, and time-constrained searches in grasslands areas susceptible to flooding. Species richness was higher in the restinga, but lower than the observed in other Brazilian biomes, possibly associated with more unstable microclimate conditions and low habitat complexity (vertical and horizontal distribution of the vegetation) in this habitat. This hypothesis is supported by the fact that the most abundant species of both snakes and lizards have fossorial habits. The assemblage of snakes is apparently mainly determined by abiotic characteristics of the habitat, while the assemblage of lizards, by vegetation cover.
\end{abstract}

Keywords: diversity, lizards, restinga, sand dunes, snakes.

SANTOS, M.B., OLIVEIRA, M.C.L.M. \& TOZETTI, A.M. Diversidade e uso do ambiente por serpentes e lagartos em ambientes costeiros do extremo sul brasileiro. Biota Neotrop. 12(3): http://www.biotaneotropica. org.br/v12n3/pt/abstract?article+bn01812032012

Resumo: O estudo teve como objetivo avaliar a composição de espécies de serpentes e lagartos em ambientes costeiros no extremo sul brasileiro. Foram feitas amostragens sistematizadas em hábitats de dunas e restingas entre abril de 2009 e março de 2010 por meio de armadilhas de interceptação e queda, abrigos artificiais e procuras visuais. $\mathrm{O}$ ambiente de restinga revelou uma maior riqueza de espécies do que as dunas. As taxocenoses revelaram uma menor riqueza do que a observada em outros biomas brasileiros, o que parece estar associado às condições microclimáticas menos estáveis e à baixa complexidade estrutural desses habitats (distribuição vertical e horizontal da vegetação). Essa hipótese parece ser reforçada pelo fato de tanto para serpentes quanto para lagartos as espécies mais abundantes apresentam hábitos fossoriais. Aparentemente a taxocenose de serpentes é determinada predominantemente pelas características abióticas (microclima) do habitat enquanto que a de lagartos pelo padrão de cobertura vegetal.

Palavras-chave: diversidade, dunas, lagartos, restinga, serpentes. 


\section{Introduction}

In the last decades, several studies on assemblages of snakes and lizards have been conducted in the Neotropics, broadening the understanding of the diversity patterns of these groups (DiBernardo et al. 2007). However, the number of studies is still low when compared to those in Europe, North America, and Australia (Seigel \& Collins 1993). This also occurs in Brazil, which houses a large diversity of Squamata (Di-Bernardo et al. 2007). Currently, 241 Brazilian species of lizard and 371 species of snakes have been described (Bérnils 2010). Unfortunately, generalizations on the patterns of regional diversity of Squamata in Brazil are limited, as most studies available focus on forest habitats (e.g. Marques \& Sazima 2004, Bernarde \& Abe 2006, Sawaya et al. 2008) and most recently in Cerrado (e.g. Colli et al. 2002, Costa et al. 2007, Sawaya et al. 2008). In Rio Grande do Sul state, samplings have been concentrated in the Pampa, Araucaria forest, central depression, and northern coastal region (Maciel et al. 2003, Santos et al. 2005, Zanella \& Cechin 2006, Winck et al. 2007).

Southern Brazil, especially the southernmost region of Rio Grande do Sul state houses 21 species of lizards and 75 species of snakes (Brasil 2004, 2008, Quintela et al. 2006, Quintela \& Loebmann 2009) and most of them are poorly studied. The municipality of Rio Grande, in Rio Grande do Sul state, harbors one of the largest continuous and relatively well-preserved areas of coastal grasslands, which are characterized by a mosaic of sand dunes and restingas. These two habitats differ, regarding patterns of plant cover and daily temperature variation (Cordazzo \& Seeliger 1987, Calliari \& Klein 1993). Despite the physical proximity between dunes and restinga, their characteristics might impose different limits for their use by snakes and lizards (Rocha \& Sluys 2005). Thus, the present study was aimed at examining differences in species composition and relative abundance in assemblages of snakes and lizards in areas of dunes and restinga in southernmost Brazil.

\section{Materials and Methods}

\section{Study area}

Samplings were conducted in a continuous area of coastal grasslands of approximately $14700 \mathrm{ha}$, located at sea level (Figure 1a), known as Balneário Cassino (32 07' 54.65" S and 52 20'53.36" O), municipality of Rio Grande, Rio Grande do Sul, Brazil. The climate is humid subtemperate with an average annual temperature of $18.1{ }^{\circ} \mathrm{C}$ (Maluf 2000). Seasons are well defined, with occasional dry periods in the spring and average annual rainfall of $1162 \mathrm{~mm}$ (Maluf 2000). During this study, between April 2009 and March 2010, the hottest months were January and February (average air temperature $=25.4^{\circ} \mathrm{C}$ ) and the coldest months were June and July (average air temperature $=11.2^{\circ} \mathrm{C}$ ). In the study period total rainfall was $1371 \mathrm{~mm}$, with November and February being the wettest $\left(\sum=527.9 \mathrm{~mm}\right)$ and July and March the driest months $\left(\sum=63.3 \mathrm{~mm}\right.$; Figure 2). Climate data were obtained from weather station $\# 83995$ of Rio Grande (EM 83995-INMET).

Two distinct habitats were sampled: (1) coastal grasslands associated with coastal dunes (hence termed "dune habitat"; Figure $1 \mathrm{~b}$ ) and (2) coastal grasslands associated with restinga (termed "restinga habitat"; Figure 1c).

The vegetation in the dune habitat consists of grasses and shrubs [e.g. Panicum racemosum (P. Beauv.) and Senecio crassiflorus (Poir.), Calliari \& Klein (1993)]. Because of the ground cover and sandy soil, daily temperatures in the dunes vary widely $\left(0-40{ }^{\circ} \mathrm{C}\right.$, Calliari $\&$ Klein 1993). The vegetation in the restinga habitat is composed of predominantly shrubs and trees [e.g. Lithraea brasiliensis Marchand and Chrysophyllum marginatum (Hook. \& Arn.), which provide significant amounts of leaf litter (Dorneles \& Waechter 2004). The higher density and taller vegetation in the restinga provide more micro-climatic stability, and therefore the daily temperature variation is not as wide as in the dunes (Rocha \& Sluys 2005).

\section{Field work}

The study was carried out between April 2009 and March 2010. The following methods were used to capture snakes and lizards:

a) Pitfall traps with drift fence (PDF) - consisted of $40 \mathrm{~m}$ lines with four buckets connected by a $50 \mathrm{~cm}$ high nylon drift fence (for details see Sawaya et al. 2008). Three groups were set up at least $600 \mathrm{~m}$ apart in each examined habitat (dunes and restingas). Each group consisted of two lines of buckets, totaling 12 lines, $480 \mathrm{~m}$ of drift fence and 48 buckets ( 24 in each examined habitat). To minimize the effects of plant cover heterogeneity among groups, we selected visually similar areas regarding density and structure of the vegetation. Uncovered buckets were inspected during a period of five consecutive days, repeated every 15 days, totaling 120 sampling days. After 12 months of collection, 5.760 pitfall traps were monitored;

b) Artificial shelters (AS) - We installed three shelters for each line of traps, two located at the opposite sides of the line and one in the center (approximately $5 \mathrm{~m}$ from buckets), totaling 36 artificial shelters. Each AS consisted of a wood board of $1 \mathrm{~m}^{2}$ and approximately $6 \mathrm{~mm}$ thick, placed on the ground after clearing the vegetation (Parmelee \& Fitch 1995). The inspection of shelters was carried out simultaneously to PDF, totaling 5.184 inspections throughout the study;

c) Time constrained visual searches (TCVS) - we conducted 20 hours/man of search per month equally distributed between dune and restinga habitats, totaling 240 hours/man (Martins \& Oliveira 1998); and

d) Incidental encounters (IC) - This method was used exclusively to complement the list of species and included animals found during activities other than those previously described.

The identification of specimens was based on available identification keys (Quintela \& Loebmann 2009, Achaval \& Olmos 2003), as well as consultation of materials from collections of other institutions. Nomenclature followed the Brazilian List of Reptiles of the Sociedade Brasileira de Herpetologia (Bérnils 2010).

\section{Data analysis}

Catches taken by TCVS and IC were used only for making the list of local species. To evaluate the efficiency of PDF and AS (the only methods that allow controlled sampling effort), an average curve of species accumulations (collector's curve) was calculated with the software Estimates 8.2.0 (Colwell 2009), adjusted for 1000 iterations. The final average curve represented the average values of its points. The data obtained for each group of traps and their corresponding shelters, during a period of five days were considered one sample, with a total of 138 samples (6 groups and 23 sample periods).

Five richness estimators were tested for precision: Chao 1 and 2, Jacknife 1 and 2 and ACE. Chao 1 was chosen for stabilizing quickly and constancy of the extrapolated value for 1000 random iterations calculated with the software Estimates 8.2.0 (Colwell 2009). To examine the participation of each species in the assemblage composition, we also calculated dominance with the rarefaction method using the software Ecosim (Gotelli \& Entsminger 2001), adjusted for 1000 iterations. Number of captures obtained for the two habitats were compared with the Mann-Withney test (exclusively for species with more than 10 captures, sensu Zar 1999). 

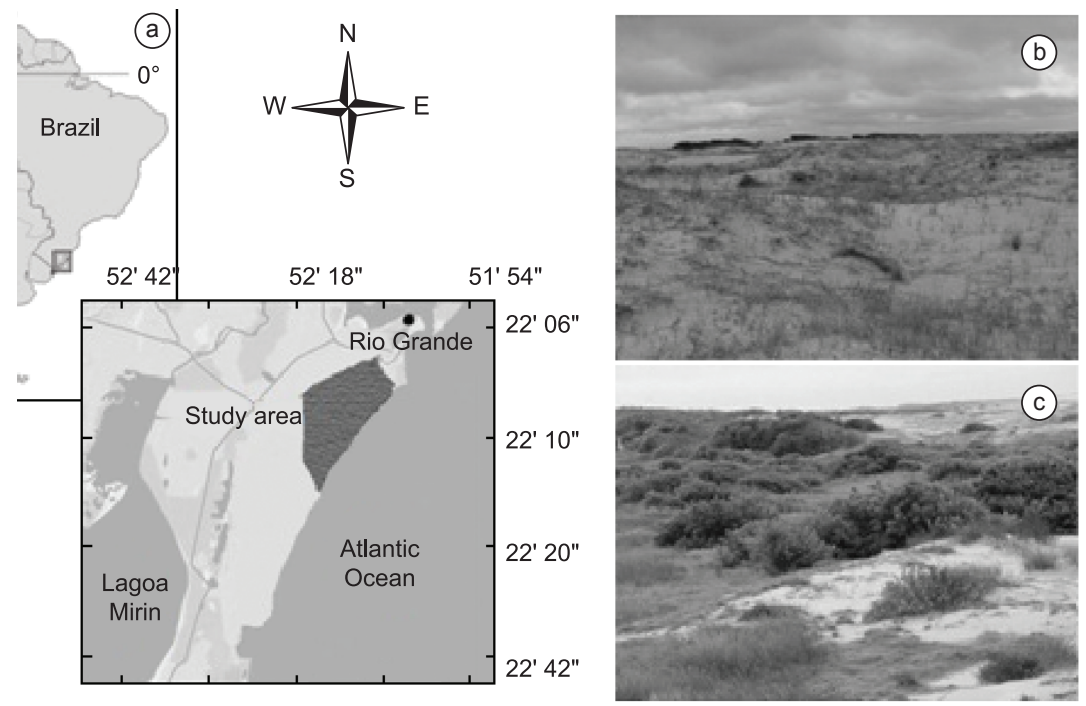

Figure 1. a) Geographic location of the study area; samplings were carried out in the area highlighted in the map. b) General aspect of the dune habitat. c) General aspect of the restinga habitat.

Figura 1. a) Localização geográfica da área de estudos; as amostragens foram realizadas na área destacada no mapa. b) Aspectos gerais do habitat de dunas. c) Aspectos gerais do habitat de restinga.

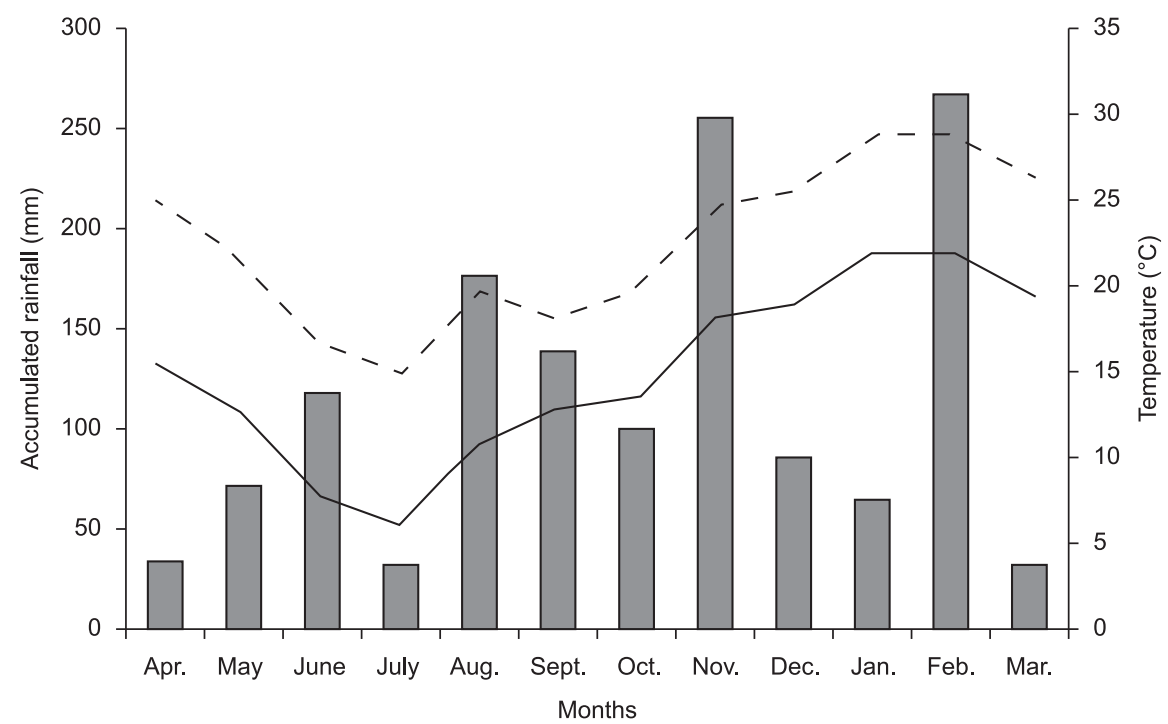

Figure 2. Accumulated rainfall variation (bars), maximum (dashed lines) and minimum temperatures (line), between April 2009 and March 2010 in the study area, in the municipality of Rio Grande, RS. Source: EM 83995-INMET.

Figura 2. Variação da pluviosidade acumulada (barras), temperaturas máxima (linha pontilhada) e mínima (linha contínua), entre abril de 2009 e março de 2010 na área de estudo, município do Rio Grande, RS. Fonte: EM 83995-INMET.

Were used a cluster analysis using the Sorensen's index of similarity to compare the species composition of the study area with those of other habitats. In the comparison, only species with genus and species epithets were included. Assemblages of snakes and lizards were analyzed separately due to ecological differences and to facilitate comparisons with other studies. The species composition was compared with those of other localities and biomes according to the classification by IBGE (Instituto... 2011). For snakes, the following studies were compared: Amazon rainforest - Martins (1991); Atlantic rainforest - Zanella \& Cechin (2006), Hartmann et al. (2009) and Borges-Martins et al. (2007); Cerrado - Sawaya et al. (2008) and Souza et al. (2010); Caatinga - Loebmann \& Hadaad (2010);
Pantanal - Strüssmann \& Sazima (1993); Coastal environment of Uruguay - Carreira et al. (2005); Argentine Chaco - Leynaud \& Bucher (1999); Pampa - Santos et al. (2005), Quintela \& Loebmann (2009) and this study. For lizards, we selected: Amazon rainforest - Ilha \& Dixo (2010) and Silva et al. (2011); Atlantic rainforest - Carvalho et al. (2007), Costa et al. (2009), Silva-Soares et al. (2011), Freire (1996) and Teixeira (2001); Cerrado - Valdujo et al. (2009) and Cintra et al. (2009); Chaco region in Argentina - Cabrera (2009) and Álvarez et al. (2009); Coastal environment of Uruguay - Carreira et al. (2005); Pampa - Santos et al. (2005), Quintela \& Loebmann (2009) and this study. 


\section{Results}

\section{Snakes}

\subsection{Richness and dominance}

Thirteen species from two families, Dipsadidae (12 species and $98.1 \%$ of captures) and Viperidae (one species, $1.79 \%$ of captures; Table 1), were captured. The three most abundant genera were Liophis (three species, $56.3 \%$ of captures), Xenodon (one species, $18.75 \%$ of captures) and Phalotris (one species, $98.21 \%$ of captures; Table 1).

For the analysis of species richness, we only included captures obtained using PDF and AS. The species accumulation curve did not stabilize (Figure 3), indicating that new samplings would increase the number of snake species. Species richness was higher in the restinga (nine species) than in the dune habitat (six species). Additionally, the estimated richness (Chao1) of snakes was higher for the restinga $(9.68 \pm 3.04)$ than for dunes $(5.93 \pm 1.15)$.

The dominance observed for the dune habitat was lower $(0.40)$ than that of the restinga (0.43). Although the number of captures in the dunes $(n=181)$ was higher than that of the restinga $(n=79)$, this difference was not significant $(\mathrm{U}=2248.5, \mathrm{p}=0.574, \mathrm{n}=138)$. The same occurred when species were examined individually. In the dunes, the most abundant species were Liophis poecilogyrus ( $40.62 \%$ of captures), Xenodon dorbignyi ( $26.56 \%$ of captures) and Liophis jaegeri (12.6\% of captures; Table 1). In the restinga, the three most abundant species were L. poecilogyrus (43.75\% of captures),
Phalotris lemniscatus (16.66\% of captures) and L. jaegeri $(12.5 \%$ of captures; Table 1). The snakes Boiruna maculata and Helicops infrataeniatus were observed only in the dunes, while Oxyrhopus rhombifer, Philodryas aestiva and Rhinocerophis alternatus, only in the restinga (Table 1).

\subsection{Comparison of snake assemblages from other localities}

The number of species found in this study $(\mathrm{n}=13)$ was less than the total species in all areas compared (Table 2). The cluster analysis revealed that the snake assemblage described in the present study is most similar to those of the Coastal environment of Uruguay (Careira et al. 2005), Atlantic rainforest from south of Brazil and Pampa habitats (Table 2; Figure 4). Similarity was lowest when compared to assemblages of the Atlantic Rainforest in southeastern Brazil (Hartmann et al. 2009) and other open habitats (e.g. Cerrado, Pantanal and Chaco; Figure 4).

\section{Lizards}

\subsection{Richness and dominance}

We captured two hundred lizards from five species distributed in five families, Liolaemidae (64.5\% of captures), Gymnophtalmidae (30\% of captures), Scincidae (3\% of captures), Teiidae $(1.5 \%$ of captures) and Anguidae (1\% of captures; Table 3$)$. Specimens of the latter family represent a new species that is currently being described (M. Borges Martins, personal comment.).

Table 1. Snake species captured in dune and restinga habitats in the municipality of Rio Grande, RS.

Tabela 1. Espécies de serpents capturadas nso habitats de dunas e restinga no município do Rio Grande, RS.

\begin{tabular}{|c|c|c|c|c|c|c|c|c|c|c|c|c|c|c|c|}
\hline \multirow{2}{*}{ Family } & \multirow{2}{*}{ Species } & \multicolumn{6}{|c|}{ Dunes } & \multicolumn{6}{|c|}{ Restinga } & \multicolumn{2}{|c|}{ Total } \\
\hline & & $\mathbf{A S}$ & PDF & IO & TCVS & $\mathbf{T}$ & $\mathbf{A \%}$ & $\mathbf{A S}$ & PDF & IO & TCVS & $\mathbf{T}$ & $\mathbf{A \%}$ & TG & $\mathbf{T} \%$ \\
\hline \multicolumn{16}{|l|}{ Dipsadidae } \\
\hline & Boiruna maculata (Boulenger, 1896) & 0 & 0 & 1 & 0 & 1 & 1.56 & 0 & 0 & 0 & 0 & 0 & 0 & 1 & 0.9 \\
\hline & Helicops infrataeniatus (Jan, 1865) & 0 & 0 & 1 & 0 & 1 & 1.56 & 0 & 0 & 0 & 0 & 0 & 0 & 1 & 0.9 \\
\hline & Liophis jaegeri (Günther, 1858) & 3 & 0 & 1 & 4 & 8 & 12.6 & 2 & 3 & 0 & 1 & 6 & 12.5 & 14 & 12.5 \\
\hline & Liophis semiaurius (Cope, 1862) & 0 & 0 & 1 & 0 & 1 & 1.56 & 0 & 1 & 0 & 0 & 1 & 2.09 & 2 & 1.78 \\
\hline & Liophis poecilogyrus (Wied, 1824) & 13 & 3 & 1 & 9 & 26 & 40.62 & 6 & 4 & 4 & 7 & 21 & 43.75 & 47 & 41.97 \\
\hline & $\begin{array}{l}\text { Oxyrhopus rhombifer Duméril, } \\
\text { Bibron \& Duméril, } 1854\end{array}$ & 0 & 0 & 0 & 0 & 0 & 0 & 0 & 1 & 0 & 0 & 1 & 2.09 & 1 & 0.9 \\
\hline & $\begin{array}{l}\text { Phalotris lemniscatus } \\
\text { (Duméril, Bibron \& Duméril, 1854) }\end{array}$ & 0 & 1 & 0 & 1 & 2 & 3.13 & 0 & 4 & 4 & 0 & 8 & 16.66 & 10 & 8.92 \\
\hline & $\begin{array}{l}\text { Philodryas aestiva } \\
\text { (Duméril, Bibron \& Duméril, 1854) }\end{array}$ & 0 & 0 & 0 & 0 & 0 & 0 & 0 & 2 & 0 & 0 & 2 & 4.16 & 2 & 1.78 \\
\hline & $\begin{array}{l}\text { Philodryas patagoniensis } \\
\text { (Girard, 1857) }\end{array}$ & 2 & 1 & 0 & 0 & 3 & 4.68 & 0 & 0 & 1 & 0 & 1 & 2.08 & 4 & 3.58 \\
\hline & Psomophis obtusus (Cope, 1984) & 0 & 0 & 0 & 1 & 1 & 1.56 & 0 & 1 & 0 & 0 & 1 & 2.09 & 2 & 1.78 \\
\hline & $\begin{array}{l}\text { Thamnodynastes hypoconia } \\
\text { (Cope, 1860) }\end{array}$ & 0 & 3 & 0 & 1 & 4 & 6.26 & 0 & 1 & 0 & 0 & 1 & 2.09 & 5 & 4.46 \\
\hline & $\begin{array}{l}\text { Xenodon dorbignyi } \\
\text { (Duméril, Bibron \& Duméril, 1854) }\end{array}$ & 0 & 8 & 1 & 8 & 17 & 26.56 & 0 & 2 & 2 & 0 & 4 & 8.33 & 21 & 18.75 \\
\hline \multicolumn{16}{|l|}{ Viperidae } \\
\hline & $\begin{array}{l}\text { Rhinocerophis alternatus } \\
\text { (Duméril, Bibron \& Duméril, 1854) }\end{array}$ & 0 & 0 & 0 & 0 & 0 & 0 & 0 & 0 & 2 & 0 & 2 & 4.16 & 2 & 1.78 \\
\hline Total of ca & tures & 18 & 16 & 6 & 24 & 64 & 100 & 8 & 19 & 13 & 8 & 48 & & 112 & 100 \\
\hline
\end{tabular}

AS = captures in artificial shelters; $\mathrm{PDF}=$ captures with pitfall traps with drift fence; $\mathrm{IO}=$ incidental encounters; TCVS = captures during time constrained visual searches; $\mathrm{T}=$ number of individuals captured per habitat; $\mathrm{TG}=$ total capture in dunes and restinga; $\mathrm{A} \%=$ percentage in relation to the total of individuals captured per habitat and $\mathrm{T} \%=$ percentage in relation to the total of individuals captured in the two habitats combined.

$\mathrm{AS}=$ capturas em abrigos artificiais; PDF = capturas em armadilhas de interceptação e queda; IO = encontros ocasionais; TCVS = capturas por procura visual limitada por tempo; $\mathrm{T}$ = número de indivíduos capturados por habitat; $\mathrm{TG}=$ total de capturas em dunas e restinga; $\mathrm{A} \%=$ porcentagem em relação ao total de indivíduos capturados por habitat e T\% = porcentagem em relação ao total de indivíduos capturados nos dois habitats. 
Santos, M.B. et al.

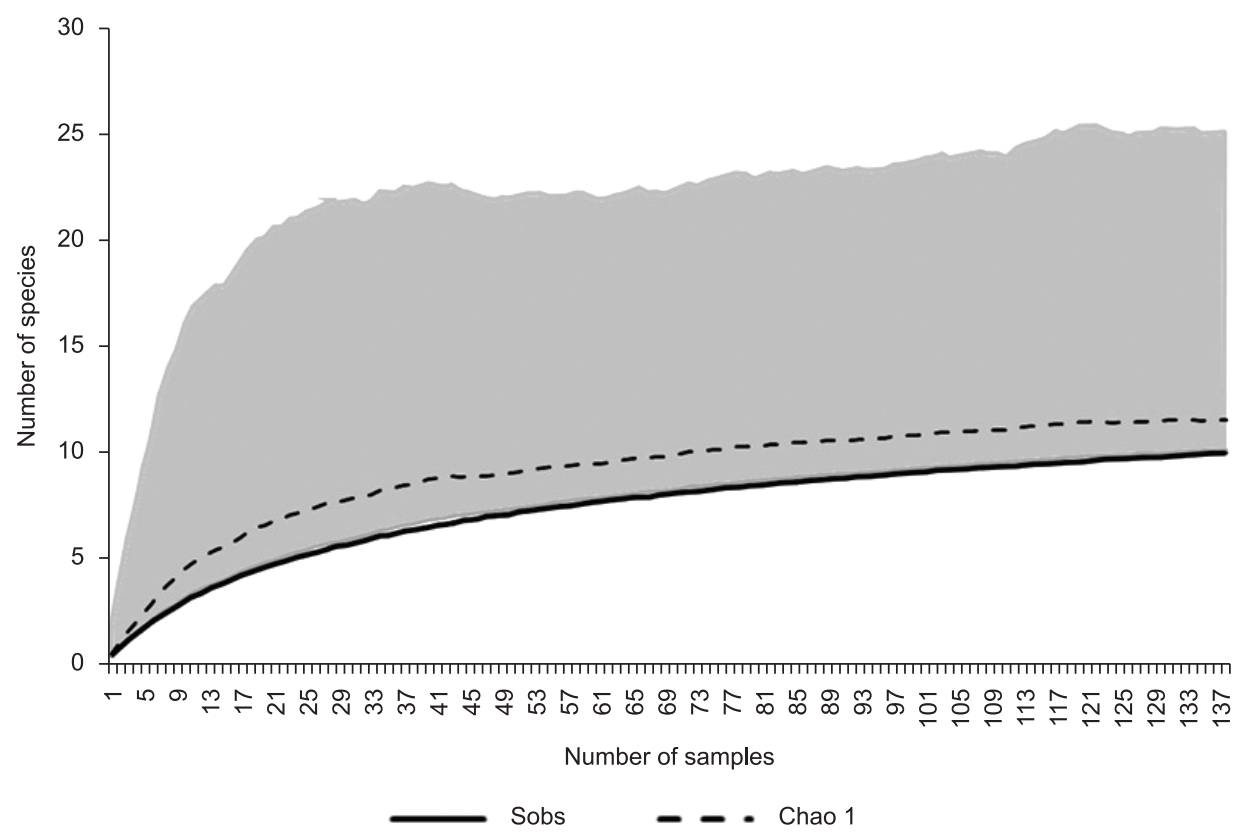

Figure 3. Accumulation curve of snake species captured between April 2009 and March 2010 in dune and restinga habitats in southernmost Brazil. The curves represent the number of species observed (Sobs) and the number generated by the richness estimator Chaol. The points represent the average of 1000 curves generated with a random order of samples. The gray area represents the standard deviation associated with the mean of 1000 curves generated by the random order of samples.

Figura 3. Curva de acumulação de espécies de serpentes capturadas entre abril de 2009 e março de 2010 nos habitats de dunas e restinga no extremo sul do Brasil. As curvas representam o número de espécies capturadas (Sobs) e o número gerado pelo estimador de riqueza Chao 1. Os pontos representam a média de 1000 curvas geradas com uma ordem aleatória de amostras. A área cinza representa o desvio padrão associado à média de 1000 curvas geradas pela ordem aleatória de amostras.

Table 2. Number of snake species found in 14 different areas of Brazil, Argentina and Uruguay.

Tabela 2. Número de espécies de serpentes encontradas em 14 áreas diferentes no Brasil, Argentina e Uruguai.

\begin{tabular}{lccc}
\hline \multicolumn{1}{c}{ Authors } & Country & Biome & Richness \\
\hline Martins (1991) & Brazil & Amazon rainforest & 64 \\
Leynaud \& Bucher (1999) & Argentina & Eastern Chaco & Western Chaco \\
Leynaud \& Bucher (1999) & Argentina & Caatinga & 37 \\
Loebmann \& Haddad (2010) & Brazil & Cerrado & 37 \\
Sawaya et al. (2008) & Brazil & Atlantic rainforest \\
Hartmann et al. (2009) & Brazil & Pantanal \\
Strüssmann \& Sazima (1993) & Brazil & Non coastal Pampa \\
Santos et al. (2005) & Brazil & Atlantic rainforest \\
Borges-Martins et al. (2007) & Brazil & Coastal Pampa \\
Quintela \& Loebmann (2009) & Brazil & Atlantic rainforest \\
Zanella \& Cechin (2006) & Brazil & Cerrado & 36 \\
Souza et al. (2010) & Brazil & Coastal environment & 24 \\
Carreira et al. (2005)* & Uruguay & Coastal Pampa \\
Present study & Brazil & 19 \\
\hline
\end{tabular}

\footnotetext{
${ }^{1}$ Department of Rocha (Uruguay); *List of species obtained based on the compilation of several studies conducted in Uruguay.
}

${ }^{1}$ Departamento de Rocha (Uruguai); *Lista de espécies obtida através da compilação de diversos estudos realizados no Uruguai.

The species accumulation curve (captures in AS and PDF) approached stability (Figure 5). The observed richness in the restinga habitat (five species) was higher than that of dunes (four species). Also, the estimated richness (Chao 1) of lizards was higher for the restinga $(4.74 \pm 1.08)$ than for the dune habitat $(3.58 \pm 0.61)$.

The dominance observed for the dunes was higher (0.66) than that of that of the restinga (0.57). The number of captures of lizards was significantly different between habitats $(U=1822, p=0.001$, $\mathrm{n}=138)$, higher in the dunes $(\mathrm{n}=147)$ than that in restinga $(\mathrm{n}=52$;
Table 3). In both habitats, Liolaemus occipitalis was the most abundant species with 90 captures for the dunes and 30 for the restinga $(41.34 \%$ of the total of captures), followed by Cercosaura schreibersii, with 45 captures in the dunes and 15 in the restinga (19.23\% of the total of captures; Table 3).

For L. occipitalis $(\mathrm{U}=1789.5, \mathrm{p}=0.011, \mathrm{n}=138)$ and C. schreibersii $(\mathrm{U}=1894.5, \mathrm{p}=0.038, \mathrm{n}=138)$, the number of captures was higher in the dunes ( $\mathrm{n}=98$ and 45 , respectively) than in the restinga ( $\mathrm{n}=30$ and 15; Table 3 ). The lizard L. occipitalis 


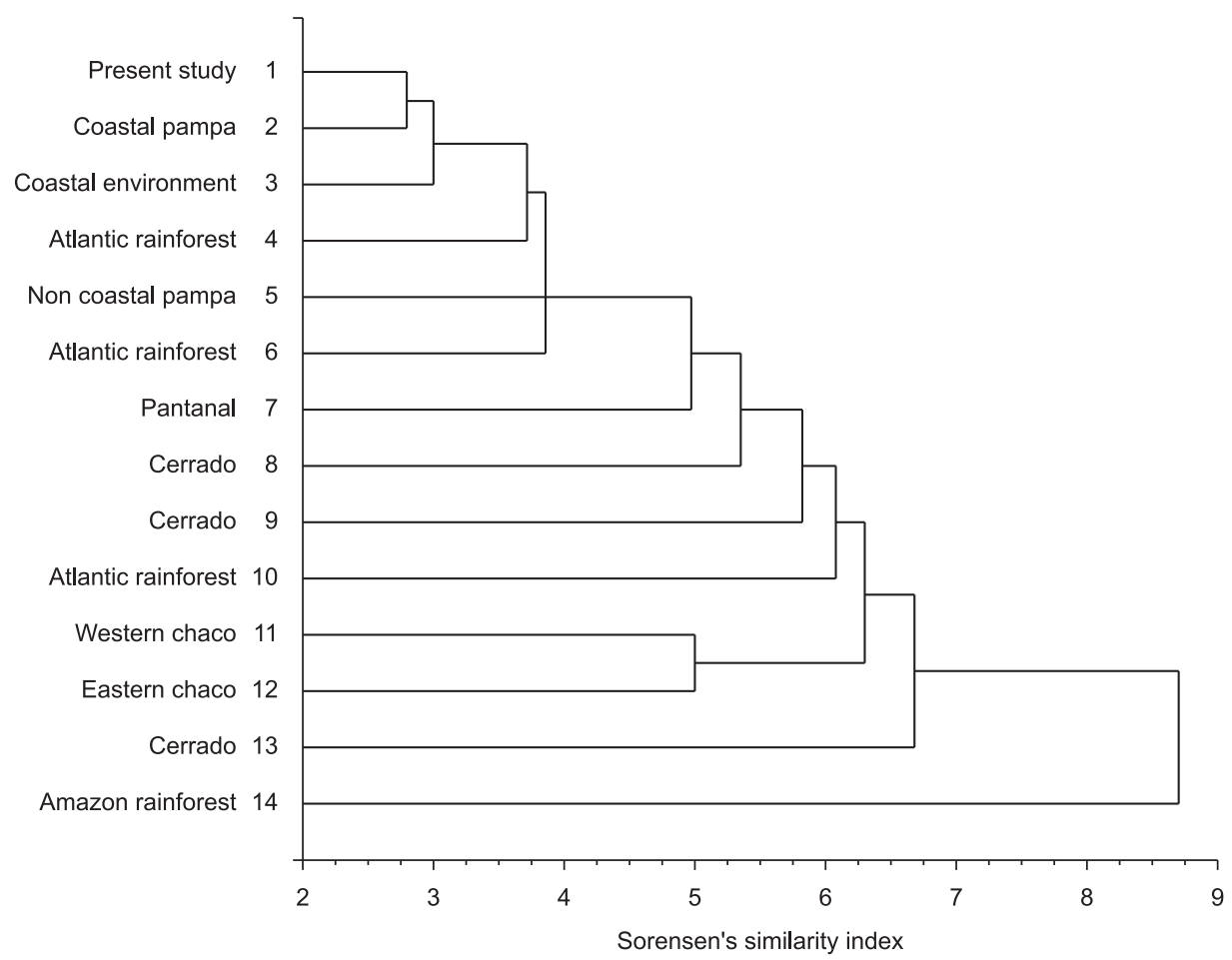

Figure 4. Dendrogram of the grouping analysis based on the composition (presence and absence) of 189 snake species distributed in 14 assemblages. 1) Present study; 2) Quintela \& Loebmann (2009); 3) Carreira et al. (2005); 4) Borges-Martins et al. 2007; 5) Santos et al. (2005); 6) Zanella \& Cechin (2006); 7) Strüssmann \& Sazima (1993); 8) Souza et al. (2010); 9) Sawaya et al. (2008); 10) Hartmann et al. (2009); 11) Leynaud \& Bucher (1999); 12) Leynaud \& Bucher (1999); 13) Loebmann \& Hadaad (2010); 14) Martins (1991).

Figura 4. Dendrograma de análise de agrupamento baseada na composição (porcentagem e abundância) de 189 espécies de serpentes distribuídas em 14 assembléias. 1) Presente estudo; 2) Quintela \& Loebmann (2009); 3) Carreira et al. (2005); 4) Borges-Martins et al. 2007; 5) Santos et al. (2005); 6) Zanella \& Cechin (2006); 7) Strüssmann \& Sazima (1993); 8) Souza et al. (2010); 9) Sawaya et al. (2008); 10) Hartmann et al. (2009); 11) Leynaud \& Bucher (1999); 12) Leynaud \& Bucher (1999); 13) Loebmann \& Hadaad (2010); 14) Martins (1991).

Table 3. Lizard species captured in dune and restinga habitats in the municipality of Rio Grande, RS.

Tabela 3. Espécies de lagartos capturadas em habitats de dunas e restinga no município do Rio Grande, RS.

\begin{tabular}{|c|c|c|c|c|c|c|c|c|c|c|c|c|c|c|}
\hline \multirow{2}{*}{ Family } & \multirow{2}{*}{ Species } & \multicolumn{6}{|c|}{ Dunes } & \multicolumn{6}{|c|}{ Restinga } & Total \\
\hline & & AS & PDF & IO & TCVS & $\mathbf{T}$ & A\% & AS & PDF & IO & TCVS & $\mathbf{T}$ & $\mathbf{A \%}$ & TG T\% \\
\hline
\end{tabular}

Anguidae

Gymnophthalmidae

Ophiodes sp.

Cercosaura schreibersii

Wiegmann, 1834

Scincidae

$\begin{array}{llllllllllllllll}\text { Mabuya dorsivittata } & 3 & 0 & 0 & - & 3 & 2.03 & 3 & 0 & 0 & - & 3 & 5.77 & 6 & 3\end{array}$

Teiidae

Cope, 1862

$\begin{array}{lllllllllllllll}\text { Tupinambis merianae } & 0 & 0 & 0 & - & 0 & 0 & 1 & 2 & 0 & - & 3 & 5.77 & 3 & 1.5\end{array}$

Liolaemidae (Duméril \& Bibron, 1839)

$\begin{array}{llllllllllllllll}\text { Liolaemus occipitalis } & 0 & 98 & 1 & - & 99 & 66.89 & 0 & 30 & 0 & - & 30 & 57.7 & 129 & 64.5\end{array}$
Boulenger, 1885

Total

$\begin{array}{llllllllllllll}46 & 101 & 1 & - & 148 & 100 & 19 & 33 & 0 & 0 & 52 & 100 & 200 & 100\end{array}$

$\mathrm{AS}=$ captures in artificial shelters; PDF = capture with pitfalls with drift fence; IE = captures during incidental encounters; TCVS = captures during timeconstrained visual searches; $\mathrm{T}=$ number of individuals captured for the habitat; $\mathrm{TG}=$ total captures in dunes and restinga; $\mathrm{A} \%=$ percentage in relation to the total number of individuals captured per habitat and $\mathrm{T} \%=$ percentage in relation to the total number of individuals captured in the two habitats combined. $\mathrm{AS}=$ capturas em abrigos artificiais; $\mathrm{PDF}=$ capturas em armadilhas de interceptação e queda; $\mathrm{IO}=$ encontros ocasionais; TCVS = capturas por procura visual limitada por tempo; $\mathrm{T}$ = número de indivíduos capturados por habitat; $\mathrm{TG}=$ total de capturas em dunas e restinga; $\mathrm{A} \%=$ porcentagem em relação ao total de indivíduos capturados por habitat e T\% = porcentagem em relação ao total de indivíduos capturados nos dois habitats. 
Santos, M.B. et al.

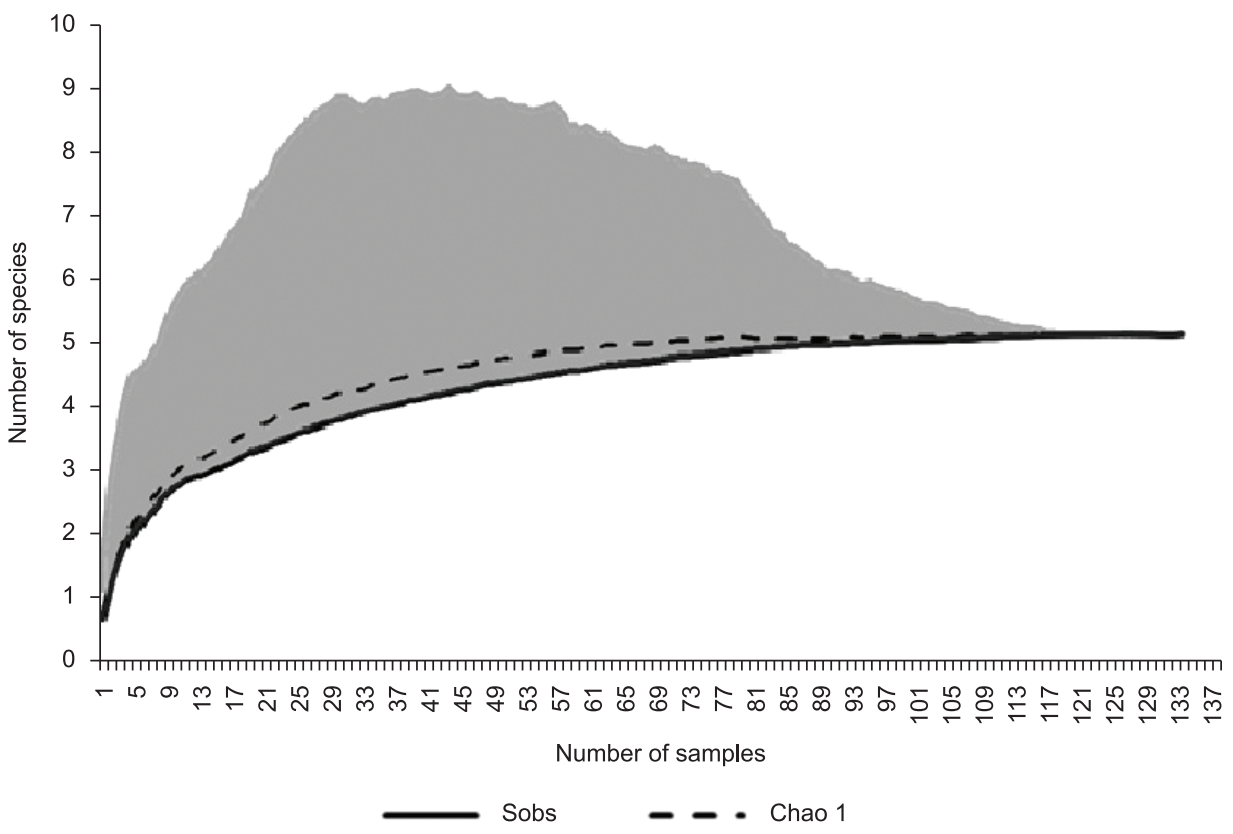

Figure 5. Species accumulation curve of lizards captured between April 2009 and March 2010 in dune and restinga habitats in the municipality of Rio Grande, RS. The curves represent the number of species observed (Sobs) and the number generated by the richness estimator Chao 1 . The points represent the average of 1,000 curves generated with a random order of samples. The gray area represents the standard deviation associated with the mean of 1000 curves generated by the random order of samples.

Figura 5. Curva de acumulação de espécies de lagartos capturados entre abril de 2009 e março de 2010 nos habitats de dunas e restinga no município do Rio Grande, RS. As curvas representam o número de espécies observadas (Sobs) e o número gerado pelo estimador de riqueza Chao 1. Os pontos representam a média de 1000 curvas geradas com uma ordem aleatória de amostras. A área cinza representa o desvio padrão associado à média de 1000 curvas geradas pela ordem aleatória de amostras.

was only captured by PDF and Mabuya dorsivittata, only by AS. Cercosaura schreibersii had only two captures by PDF. All species of lizards were observed in both habitats, except for Tupinambis merianae, captured only in the restinga (Table 3).

\subsection{Comparison with lizard assemblages from other localities}

The number of species of lizards found in this study $(n=5)$ was lower than those found in compared studies (Table 4).

Cluster analysis revealed that the assemblage of lizards studied has greater similarity with areas of Pampa, Coastal environment of Uruguay and Eastern Chaco in Argentina (Table 4; Figure 6). The dendrogram revealed a distinction between open and forested habitats. Similarity was lowest between assemblages of forest and that of the present study.

\section{Discussion}

Despite the intense sampling effort and the combination of capture methods, the non-stabilization of the collector's curve suggests that the species richness of snakes in the study area is still higher than that recorded. The numbers of species found in this study represents $68 \%$ of the snake species and $62 \%$ of the lizard species previously recorded in the municipality (Quintela et al. 2006). This indicates the importance of dune and restinga habitats for the region. The relatively low species richness compared to other Brazilian assemblages might be due to historical factors (Seeliger 1997), an abiotic filter created by the wide daily temperature variation, as well as the harsh winter for tropical standards (Maluf 2000). These factors associated to strong coastal winds (Calliari \& Klein 1993), make these habitats less susceptible for the colonization by ectotherms. Consequently, the lower richness observed in dunes compared to restinga (for snakes as well as lizards) might be associated to more severe microclimatic conditions in dunes (e.g. insolation and wide daily temperature variation) and also the lower heterogeneity in plant cover.. On the other hand this configuration should be driven by historical factors. A biogeographic approach should be helpful for subsequent studies in similar habitats.

Interestingly, two fossorial snakes were the dominant species in dunes $(X$. dorbignyi) as well as restinga ( $P$. lemniscatus). The ability to bury might increase the adaptability to dune and restinga habitats, both subjected to abrupt temperature variations at the ground surface (Tozetti et al. 2009, Oliveira et al. 2001). The dominance of semifossorial (L. occipitalis) and cryptic (C. schreibersii) species was also observed for lizards. The sandy substrate possible favors $L$. occipitalis, which buries itself in the sand and builds shelters (Santos et al. 2010, Bujes \& Verrastro 1998). In contrast, C. schreibersii, instead of burying itself, uses logs and stones as shelter (Doan 2003, pers. obs.). Although this behavior could increase its affinity for the restinga, where the leaf litter and additional accumulated plant material provide more shelters, this was not observed. The use of artificial shelters might have increased the capture of individuals of these species in the dunes (where the availability of natural shelters is low), masking differences in abundance between habitats.

The cluster analysis suggests that the type of vegetation has a secondary role in the structure of snake assemblages examined. This is supported by the higher similarity of the study area to some assemblages from forests than to those from open habitats such as Pampa or Pantanal. However, the similarity with other Coastal environments suggest a stronger abiotic influence in the structure of 
Table 4. Number of species of lizards found in 14 areas of different states, habitats and biomes of Brazil, Argentina and Uruguay, with their corresponding references.

Tabela 4. Número de espécies de lagartos encontradas em 14 áreas em diferentes estados, habitats e biomas do Brasil, Argentina e Uruguai, com suas referencias correspondentes.

\begin{tabular}{|c|c|c|c|}
\hline Authors & Country & Biome & Richness \\
\hline Cabrera (2009) & Argentina & Gran Chaco & 28 \\
\hline Valdujo et al. (2009) & Brazil & Cerrado & 26 \\
\hline Ilha \& Dixo (2010) & Brazil & Amazon Rainforest & 19 \\
\hline Silva et al. (2011) & Brazil & Amazon Rainforest & 17 \\
\hline Freire (1996) & Brazil & Atlantic Rainforest & 13 \\
\hline Cintra et al. (2009) & Brazil & Cerrado & 13 \\
\hline Álvarez et al. (2009) & Argentina & Eastern Chaco & 13 \\
\hline Carvalho et al. (2007) & Brazil & Atlantic Rainforest & 12 \\
\hline Costa et al. (2009) & Brazil & Atlantic Rainforest & 12 \\
\hline Silva-Soares et al. (2011) & Brazil & Atlantic Rainforest & 11 \\
\hline Teixeira (2001) & Brazil & Atlantic Rainforest & 8 \\
\hline Carreira et al. (2005)* & Uruguai $^{1}$ & Coastal environment & 8 \\
\hline Santos et al. (2005) & Brazil & Non coastal Pampa & 7 \\
\hline Quintela \& Loebmann (2009) & Brazil & Coastal Pampa & 7 \\
\hline Present study & Brazil & Coastal Pampa & 5 \\
\hline
\end{tabular}

${ }^{1}$ Department of Rocha (Uruguay); *List of species based on the compilation of several studies.

${ }^{1}$ Departamento de Rocha (Uruguai); *Lista de espécies baseada na compilação de diversos estudos.

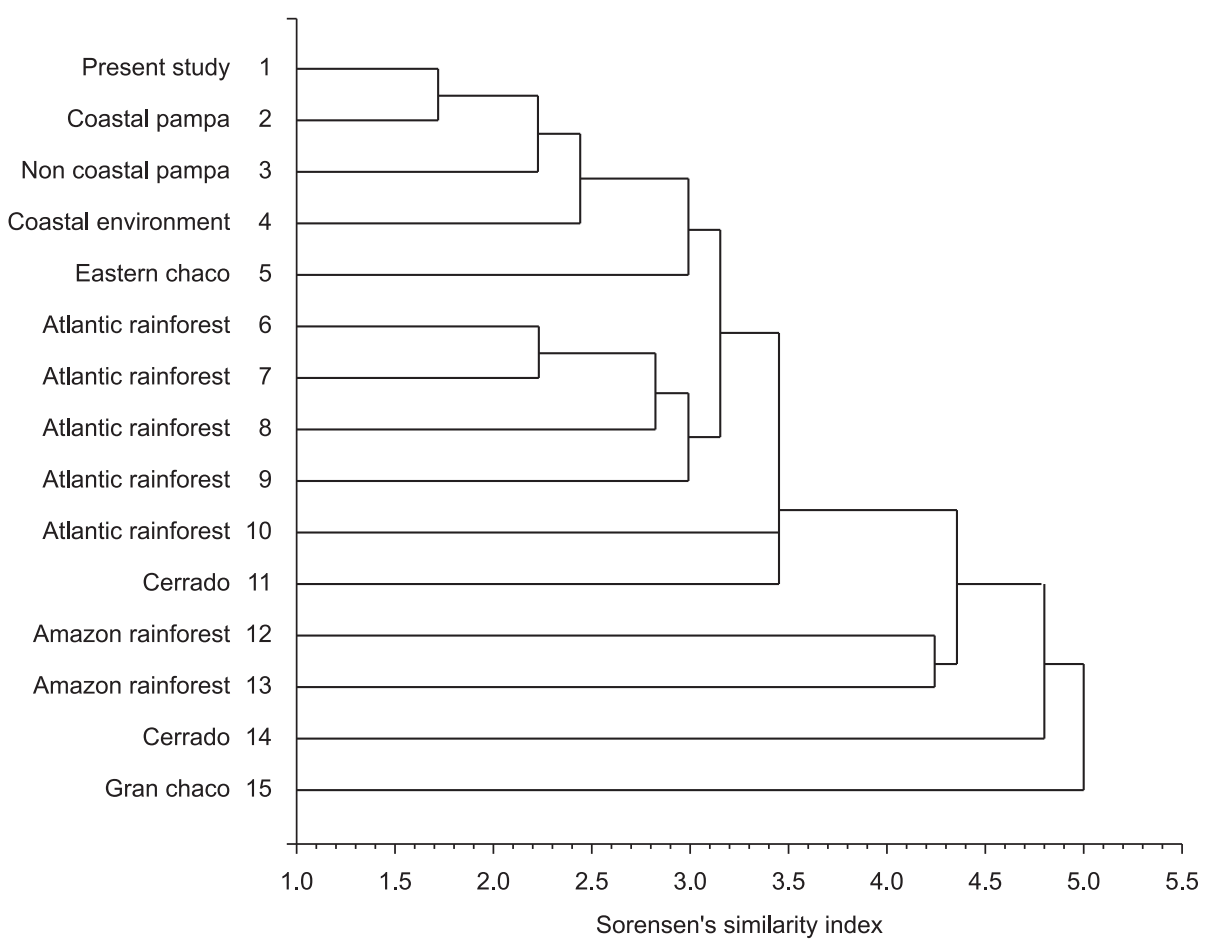

Figure 6. Dendrogram of the grouping analysis of the species composition of lizards (presence and absence of 98 species) of eight assemblages. 1) Present study; 2) Quintela \& Loebmann (2009); 3) Santos et al. (2005); 4) Carreira et al. (2005); 5) Álvarez et al. 2009; 6) Teixeira (2001); 7) Silva-Soares et al. (2011); 8) Carvalho et al. (2007); 9) Costa et al. (2009); 10) Freire (2006); 11) Cintra et al. (2009); 12) Silva et al. (2011); 13) Ilha \& Dixo (2010); 14) Valdujo et al. (2009); 15) Cabrera (2009).

Figura 6. Dendrograma de análise de agrupamento baseada na composição (porcentagem e abundância) de 189 espécies de serpentes distribuídas em 14 assembléias. 1) Presente estudo; 2) Quintela \& Loebmann (2009); 3) Santos et al. (2005); 4) Carreira et al. (2005); 5) Álvarez et al. 2009; 6) Teixeira (2001); 7) Silva-Soares et al. (2011); 8) Carvalho et al. (2007); 9) Costa et al. (2009); 10) Freire (2006); 11) Cintra et al. (2009); 12) Silva et al. 2011; 13) Ilha \& Dixo (2010); 14) Valdujo et al. (2009); 15) Cabrera (2009).

communities, which is supported by the similarity observed between the study area and the Coastal environment of Uruguay (Carreira et al. 2005). In both areas, the climatic conditions and the marine influence are similar. This abiotic filter, less favorable to ectotherms, might also be responsible for the relatively low species richness compared to other Brazilian assemblages.

Conversely, lizard assemblages showed a stronger association with plant cover. Similarity was higher with the Pampa, where climatic 
conditions are distinct from those of the Coastal environments (Maluf 2000, Santos et al. 2005). Additionally, despite the coastal influence in areas of the Atlantic Forest, the assemblages from this biome were different from that of the study area. Although the Atlantic Forests included restinga habitats, plant cover consists of an arboreal component more developed than that of the study area (Freire 1996, Teixeira 2001, Carvalho et al. 2007). This divergence suggests that plant cover pattern represent a primary filter, wich overlaps the abiotic factors in the structure of the lizard assemblages compared.

Our findings also revealed an intrinsic heterogeneity of the communities of some groups of Squamata in habitats that comprise the Brazilian coastal grasslands. Despite low endemic rates, the coastal grasslands of southernmost Brazil contain biotic and abiotic characteristics that act as important filters in the structure of snakes and lizards communities.

\section{Acknowledgements}

The authors are thankful to the researchers Alexandre Hartmann and Lucas Ott Tavaves for field work assistance, and to CNPq, FAPERGS, and Capes for financial support to conduct this study and a Master's fellowship.

\section{References}

ACHAVAL, F. \& OLMOS, A. 2003. Anfibios y Reptiles del Uruguay. 2nd ed. Graphis Impresora, Montevideo.

ÁLVAREZ, B.B., GARCIA, J.A.R., CÉSPEDEZ, J.A., HERNANDO, A.B., ZARACHO, V.H., CALAMANTE, C.C. \& AGUIRRE, R.H. 2009. Herpetofauna, provinces of Chaco and Formosa, Chaco Oriental region, north-eastern Argentina. Check List 5(1):074-082.

BERNARDE, P.S. \& ABE, A.S. 2006. A snake community at Espigão do Oeste, Rondônia, southwestern Amazon, Brazil. South. Am. J. Herpetol. 1(2):102-113. http://dx.doi.org/10.2994/18089798(2006)1[102:ASCAED]2.0.CO;2

BÉRNILS, R.S. (org.). 2010. Brazilian reptiles - List of species. Sociedade Brasileira de Herpetologia. http://www.sbherpetologia.org.br/ (último acesso em 07/08/2011).

BORGES-MARTINS, M., ALVES, M.L.M., ARAÚJO, M.L., OLIVEIRA, R.B., ANÉS, A.C. 2007. Répteis. In BECKER, F.G., RAMOS, R.A. \& MOURA, L.A. (org.). Biodiversidade. Regiões da Lagoa do Casamento e dos Butiazais de Tapes, Planície Costeira do Rio Grande do Sul. Ministério do Meio Ambiente, Secretaria de Biodiversidade e Florestas, Brasília, p.292-315

BRASIL. Ministério do Meio Ambiente - MMA. 2004. Segundo Relatório Nacional para a Convenção sobre Diversidade Biológica. Diretoria do Programa Nacional de Conservação da Biodiversidade. MMA, Brasília.

BRASIL. Ministério do Meio Ambiente - MMA. 2008. Mapa de Áreas Prioritárias para a Biodiversidade. http://www.mma.gov.br/index. php $2 \mathrm{ido}=$ conteudo. montaandidEstrutura $=72$ andidConteudo $=5454$. (ultimo acesso em 06/2008).

BUJES, C.S. \& VERRASTRO, L. 1998. Comportamento de Liolaemus occipitalis em cativeiro (Sauria:Tropiduridae). Rev. Bras. Zool. 15(4):915-920.

CABRERA, M.R. 2009. Lagartos del centro de la Argentina. Cordoba, 120p.

CALLIARI, L.J. \& KLEIN, A.H.F. 1993. Características morfodinâmicas e sedimentológicas das praias oceânicas entre Rio Grande e Chuí, RS. Pesquisas 20(1): 48-56.

CARreirA, S., MENEGHEL, M. \& ACHAVAL, F. 2005. Reptiles de Uruguay. Faculdad de Ciencias, Montevideo.

CARVALHO, A.L.G., ARAÚJO, A.F.B. \& SILVA, H.R. 2007. Lagartos da Marambaia, um remanescente insular de Restinga e Floresta Atlântica no Estado do Rio de Janeiro, Brasil. Biota Neotrop. 7(2):221-226. http:// www.biotaneotropica.org.br/v7n2/pt/abstract?inventory+bn03407022007 (ultimo acesso em 05/06/2011).
CINTRA, C.E.D., SILVA, H.L.R. \& SILVA JUNIOR, N.J. 2009. Herpetofauna, Santa Edwiges I and II hydroeletric powerplants, state of Goiás, Brazil. Check List 5(3): 570-576.

COLLI, G.R., BASTOS, R.P. \& ARAÚJO, A.F.B. 2002. The character \& dynamics of Cerrado herpetofauna. In The Cerrados of Brazil: Ecology \& Natural History of a Neotropical Savanna (P.S. Oliveira \& R.J. Marquis, eds). Columbia University Press, New York, p.223-241.

COLWELL, R.K. 2009. EstimateS: statistical estimation of species richness \& shared species from samples. versão 8.2.0. http://viceroy.eeb.uconn. edu/estimates.

CORDAZZO, C.V. \& SEELIGER, U. 1987. Composição e distribuição da vegetação nas dunas costeiras ao sul do Rio Grande (RS). Ciênc. Cult. 39(3):321-324.

COSTA, H.C., FERNANDES, V.D., RODRIGUES, A.C. \& FEIO, R.V. 2009. Lizards and Amphisbaenians, municipality of Viçosa, state of Minas Gerais, southeastern Brazil. Check List 5(3): 732-745.

COSTA, G.C., NOGUEIRA, C., MACHADO, R.B. \& COLLI, G.R. 2007. Squamate richness in the Brazilian Cerrado and its environmental-climatic associations. Divers. Distrib. 13: 714-724. http://dx.doi.org/10.1111/ j.1472-4642.2007.00369.x

DI-BERNARDO, M., BORGES-MARTINS, M., OLIVEIRA, R.B. \& PONTES, G.M.F. 2007. Taxocenoses de serpentes de regiões temperadas do Brasil. In Herpetologia no Brasil II (L.B. Nascimento \& M.E. Oliveira, eds). Sociedade Brasileira de Herpetologia, Belo Horizonte, p.222-263.

DOAN, T.M. 2003. A new phylogenetic classification for the Gymnophthalmid genera Cercosaura, Pantodactylus \& Prionodactylus (Reptilia: Squamata). Zool. J. Linn. Soc-Lond. 137(1):101-115. http://dx.doi. org/10.1046/j.1096-3642.2003.00043.x

DORNELES, L.P.P. \& WAECHTER, J.L. 2004. Estrutura do componente arbóreo da floresta arenosa de restinga do Parque Nacional da Lagoa do Peixe, Rio Grande do Sul. Hoehnea 31(1):61-71.

FREIRE, E.M.X. 1996. Estudo ecológico e zoogeográfico sobre a fauna de lagartos (sauria) das dunas de Natal, Rio Grande do Norte e da restinga de Ponta de Campina, Cabedelo, Paraíba, Brasil. Rev. Bras. Zool. 13(4):903-921.

GOTELLI, N.J. \& ENTSMINGER, G.L. 2001. EcoSim: Null models software for ecology. version 6.0. Acquired Intelligence Inc. \& Kesey-Bear. http:// homepages.together.net/ gentsmin/ecosim.htm.

HARTMANN, P.A., HARTMANN, M.T. \& MARTINS, M. 2009. Ecologia e história natural de uma taxocenose de serpentes no Núcleo Santa Virgínia do Parque Estadual da Serra do Mar, no sudeste do Brasil. Biota Neotrop. 9(3): 173-184. http://www.biotaneotropica.org.br/v9n3/ en/abstract?article+bn03609032009 (ultimo acesso em 10/06/2011).

INSTITUTO BRASILEIRO DE GEOGRAFIAE ESTATÍSTICA- IBGE. 2011. Mapa de Biomas do Brasil. Disponível em: http://www.ibge.gov.br/ home/presidencia/noticias/noticia_visualiza.php?id_noticia=169andid_ pagina $=1$ (último acesso em 01/2011).

ILHA, P. \& DIXO, M. 2010. Anurans and Lizards, Rio Preto da Eva, Amazonas, Brazil. Check List 6(1):17-21.

LEYNAUD, G.C. \& BUCHER, E.H. 1999. La fauna de serpientes del Chaco Sudamericano: diversidad, distribución geografica y estado de conservación. Academia Nacional de Ciencias Miscelanea, v.98, p.1-46.

LOEBMANN, D. \& HADDAD, C.F.B. 2010. Amphibians \& reptiles from a highly diverse area of the Caatinga domain: composition \& conservation implications. Biota Neotrop. 10(3):227-256. http://www.biotaneotropica. org.br/v10n3/en/abstract?article+bn03910032010 (ultimo acesso em 4/06/2011).

MACIEL, A.P., DI-BERNARDO, M., HARTZ, S.M., OLIVEIRA, R.B. \& PONTES, G.M.F. 2003. Seazonal \& daily activity patterns of Liophis poecilogyrus (Serpentes: Colubridae) on the north coast of Rio Grande do Sul, Brazil. Amphibia-Reptilia 24(2):189-200. http://dx.doi. org/10.1163/156853803322390435

MALUF, J.R.T. 2000. Nova classificação climática do Estado do Rio Grande do Sul. Rev. Bras. Agromet. 8(1):141-150. 
MARQUES, O.A.V. \& SAZIMA, I. 2004. História natural dos répteis da Estação Ecológica Juréia-Itatins. In Estação Ecológica Juréia-Itatins (O.A.V. Marques \& W. Duleba, eds). Ambiente físico, flora e fauna. Holos Editora, Ribeirão Preto, p.257-277.

MARTINS, M. 1991. The Lizards of Balbina, Central Amazonia, Brazil: A Qualitative Analysis of Resource Utilization. Stud. Neotrop. Fauna E. 26(3):179-190.

MARTINS, M. \& OLIVEIRA, M.E. 1998. Natural history of snakes in forests of the Manaus region, Central Amazonia, Brazil. Herpetol. Nat. Hist. 6(2):78-150.

OLIVEIRA, R.B., DI-BERNARDO, M., PONTES, G.M.F., MACIEL, A.P. \& KRAUSE, L. 2001. Dieta e comportamento alimentar da cobra nariguda, Lystrophis dorbignyi (Duméril, Bibron \& Duméril, 1854), no Litoral Norte do Rio Grande do Sul, Brasil. Cuadernos Herpet. 14(2):117-122.

PARMELEE, J.R. \& FITCH, H.S. 1995. An experiment with artifcial shelters for snakes: effects of material age and surface preparation. Herpet. Nat. Hist. 3(2):187-191.

QUINTELA, F.M. \& LOEBMANN, D. 2009. Os répteis da região costeira do extremo sul do Brasil. USEB, Pelotas.

QUINTELA, F.M., LOEBMANN, D. \& GIANUCA, N.M. 2006. Répteis continentais do município de Rio Grande do Sul, Brasil. Biociências 14(2):180-188.

ROCHA, C.F.D. \& SLUYS, M.V. 2005. Herpetofauna de restinga. In Herpetologia no Brasil II (L.B. Nascimento \& M.E. Oliveira, eds). Sociedade Brasileira de Herpetologia, Belo Horizonte p.44-65.

SANTOS, T.G., KOPP, K.A., TREVISAN, R. \& CECHIN, S.Z. 2005. Répteis do Campus da Universidade Federal de Santa Maria, RS, Brasil. Biota Neotrop. 5(1):1-8. http://www.biotaneotropica.org.br/v5n1/pt/abstract?i nventory+BN02705012005 (ultimo acesso em 02/06/2011).

SANTOS, M.B., OLIVEIRA, M.C.L.M.O., VERRASTRO, L. \& TOZETTI, A.M. 2010. Playing dead to stay alive: death-feigning in Liolaemus occipitalis (Squamata: Liolaemidae). Biota Neotrop. 10(4):360-364. http://www.biotaneotropica.org.br/v10n4/en/abstract?shortcommunication+bn03110042010 (ultimo acesso em 02/03/2011).

SAWAYA, R.J., MARQUES, O.A.V. \& MARTINS, M. 2008. Composition \& natural history of a Cerrado snake assemblage at Itirapina, São Paulo state, southeastern Brazil. Biota Neotrop. 8(2):129-151. http://www. biotaneotropica.org.br/v8n2/en/abstract?inventory+bn01308022008 (ultimo acesso em 04/04/2011).
SEIGEL, R.A. \& COLLINS, J.T. 1993. Snakes, ecology and behavior. Mc Graw-Hill Inc., New York.

SEELIGER, U. 1997. Seagrass meadows. In Subtropical Convergence Environments: The Coast and Sea in the Southwestern Atlantic (U. Seeliger, C. Odebrecht \& J.P. Castello, eds.). Springer-Verlag, Heidelberg, New York, p.82-85.

SILVA, F.M., MENKS, A.C., PRUDENTE, A.L.C., COSTA, J.C.L., TRAVASSOS, E.M. \& GALATTI, U. 2011. Squamate Reptiles from municipality of Barcarena and surroundings, state of Pará, north of Brazil. Check List 7(3):220-226.

SILVA-SOARES, T., FERREIRA, R.B., SLLES, R.O.L. \& ROCHA, C.F.D. 2011. Continental, insular and coastal marine reptiles from the municipality of Vitória, state of Espírito Santo, southeastern Brazil. Check List 7(3):290-298.

SOUZA, F.L., UERANABARO, M., LANDGREF-FILHO, P., PIATTI, L. \& PRADO, C.P.A. 2010. Herpetofauna, municipality of Porto Murtinho, Chaco region, state of Mato Grosso do Sul, Brazil. Check List 6(3):470-475.

STRÜSSMANN, C. \& SAZIMA, I. 1993. The snake assemblage of the Pantanal at Poconé, western Brazil: Faunal composition \& ecological summary. Stud. Neotrop. Fauna E. 28(3):157-168.

TEIXEIRA, R.L. 2001. Comunidade de lagartos da Restinga de Guriri, São Mateus - ES, Sudeste do Brasil. Atlântica, Rio Grande. Atlântica 23(2):77-84

TOZETti, A.M., OliVEIRA, R.B. \& PONTES, G.M.F. 2009 Defensive repertoire of Xenodon dorbignyi (Serpentes, Dipsadidae). Biota Neotrop. 9(3): http://www.biotaneotropica.org.br/v9n3/en/ abstract?article+bn03409032009 (ultimo acesso em 03/02/2011).

VALDUJO, P.H., NOGUEIRA, C.C., BAUMGARTEN, L., RODRIGUES, F.H.G., BRANDÃO, R.A., ETEROVIC, A., RAMOS-NETO, M.B. \& MARQUES, O.A.V. 2009. Squamate Reptiles from Parque Nacional das Emas and surroundings, Cerrado of Central Brazil. Check List 5(3):405-417.

WINCK, G.R., SANTOS, T.G. \& CECHIN, S.Z. 2007. Snake assemblage in a disturbed grassland environment in Rio Grande do Sul State, Southern Brazil: population fluctuations of Liophis poecilogyrus \& Pseudablabes agassizii. Ann. Zool. Fenn. 44(2):321-332.

ZANELLA, N. \& CECHIN, S.Z. 2006. Taxocenose de serpentes no Planalto Médio do Rio Grande do Sul. Brasil. Rev. Bras. Zool. 23:211-217. http:// dx.doi.org/10.1590/S0101-81752006000100013

ZAR, J.H. 1999. Biostatistical Analysis. Prentice-Hall, New Jersey. 